\title{
Recipient BCL2 inhibition and NK cell ablation form part of a reduced intensity conditioning regime that improves allo-bone marrow transplantation outcomes
}

\author{
Yuhao Jiao ${ }^{1,2,3} \cdot$ Joanne E. Davis ${ }^{4,5} \cdot$ Jai Rautela $\mathbb{D}^{1,2} \cdot$ Emma M. Carrington $^{1,2} \cdot$ Mandy J. Ludford-Menting ${ }^{4,5} \cdot$ \\ Wilford Goh ${ }^{1,2} \cdot$ Rebecca B. Delconte $^{1,2} \cdot$ Fernando Souza-Fonseca-Guimaraes $^{1,2} \cdot$ Rachel Koldej $^{4,5} \cdot$ Daniel Gray $^{1,2}$. \\ David Huang $^{1,2} \cdot$ Ben T. Kile $\mathbb{D}^{1,2,6} \cdot$ Andrew M. Lew ${ }^{1,2,5} \cdot$ David S. Ritchie $^{4,5,7} \cdot$ Nicholas D. Huntington $\mathbb{D}^{1,2}$
}

Received: 31 May 2018 / Revised: 28 September 2018 / Accepted: 8 October 2018 / Published online: 12 November 2018

(c) ADMC Associazione Differenziamento e Morte Cellulare 2018

\begin{abstract}
Allogeneic hematopoietic stem cell transplantation (alloSCT) is used to treat over 15,000 patients with acute myeloid leukemia (AML) per year. Donor graft-versus-leukemia (GVL) effect can prevent AML relapse; however, alloSCT is limited by significant toxicity related to conditioning intensity, immunosuppression, opportunistic infections, and graft-versus-host disease (GVHD). Reducing the intensity of conditioning regimens prior to alloSCT has improved their tolerability, but does not alter the pattern of GVHD and has been associated with increased rates of graft rejection and relapse. Here, using a murine pre-clinical model, we describe a novel recipient conditioning approach combining reduced intensity conditioning with either genetic or pharmacological inhibition of NK cell numbers that permits efficient donor engraftment and promotes GVL without inducing GVHD. We show that NK cell-specific deletion of $\mathrm{Bcl} 2$ or Mcl1 in mice, or pharmacological inhibition of BCL2 impairs radio-resistant NK cell-mediated rejection of allogeneic engraftment and allows reduction of conditioning intensity below that associated with GVHD priming. The combination of reduced intensity conditioning and NK cell targeting in mice allowed successful donor $\mathrm{T}$ cell engraftment and protective immunity against AML while avoiding GVHD. These findings suggest that reduced conditioning in combination with targeted therapies against recipient NK cells may allow the delivery of effective alloSCT against AML while reducing the toxicities associated with more intensive conditioning including GVHD.
\end{abstract}

Edited by C. Borner

These authors contributed equally: Yuhao Jiao, Joanne E. Davis, David S. Ritchie, Nicholas D. Huntington

Electronic supplementary material The online version of this article (https://doi.org/10.1038/s41418-018-0228-y) contains supplementary material, which is available to authorized users.

David S. Ritchie

David.Ritchie@mh.org.au

$\triangle$ Nicholas D. Huntington

huntington@wehi.edu.au

1 The Walter and Eliza Hall Institute of Medical Research, 1G Royal Parade, Parkville, Melbourne, VIC 3052, Australia

2 Department of Medical Biology, University of Melbourne, Parkville, Melbourne, VIC 3010, Australia

3 School of Medicine, Tsinghua University, Beijing 100084, China

\section{Key Points}

- Extensive host conditioning is required to prevent natural killer cell (not CD8 T cell) mediated rejection of alloSCT yet this potentiates GVHD.

- FDA-approved BCL2 inhibitor combined with reduced TBI ablates host NK cell activity to achieve the clinical goal of successful alloSCT, robust GVL while preventing GVHD.

4 ACRF Translational Research Laboratory, The Royal Melbourne Hospital, Parkville, Melbourne, VIC 3050, Australia

5 The Department of Medicine, University of Melbourne, Parkville, Melbourne, VIC 3010, Australia

6 Anatomy and Developmental Biology, Monash Biomedicine Discovery, Institute Monash University, Melbourne, VIC, Australia

7 Clinical Haematology and Bone Marrow Transplantation Service, The Royal Melbourne Hospital, Parkville, Melbourne, VIC 3050, Australia 


\section{Introduction}

Allogeneic stem cell transplantation (alloSCT) is used to treat acute myeloid leukemia (AML) [1]. The curative potential of alloSCT in AML is largely due to the immunemediated graft-versus-leukemia (GVL) effect and dependent on the durable donor $\mathrm{T}$ cell engraftment [2]. This can be achieved by intensive myeloablative conditioning (MAC) regimens, which result in lower rates of relapse, but are associated with increased rates of transplant related mortality. Furthermore, rapid donor $\mathrm{T}$ cell engraftment coupled with the pro-inflammatory environment associated with intense conditioning also results in high rates of graftversus-host disease (GVHD).

GVHD develops in approximately $60 \%$ of alloSCT recipients and is the major determinant of post-alloSCT quality of life. The adverse outcomes of GVHD are contributed to by factors that promote allogeneic $\mathrm{T}$ cell activation and recipient tissue factors that promote tissue damage. The pro-inflammatory environment induced by high-dose chemotherapy or radiotherapy conditioning promotes the breaking of allo-tolerance and lowers the tolerance of target tissues [3,4]. The dual challenge of alloSCT is therefore to utilize a conditioning regimen that delivers donor immunosuppression sufficient for donor engraftment for the GVL effect, while limiting organ toxicity and GVHD. The advent of reduced intensity conditioned (RIC) alloSCT has allowed transplantation to be offered more safely to older recipients. However the use of RIC is associated with increased rates of delayed engraftment, increased risk of relapse, and only modest reductions in moderate to severe GVHD [5]. Novel approaches are therefore needed in order to modulate recipient immunity to allow durable donor engraftment while avoiding GVHD.

Natural killer (NK) cells are the frontline of innate lymphoid cell immunity, and are reliant on the cytokine IL-15 $[6,7]$. In the setting of alloSCT, recipient NK cells are known to be relatively resistant to conditioning and their persistence limits the engraftment of allogeneic hematopoietic stem cells [8]. We have also shown that recipient NK cells regulate the proliferation rate, activation status, and GVHD-initiating capacity of donor-derived T cells [9]. When RIC is used in this model, recipient NK cells are not suppressed and an increased likelihood of graft rejection is observed. Conversely, donor NK cell infusions administered at the time of alloSCT can reduce the rate of GVHD, and the competition between T cells and NK cells for IL-15 is likely to play a role. Indeed, GVHD impairs donor NK cell development post-alloSCT in part by reducing the available IL-15 required for NK cell homeostasis [10].

IL-15 results in the upregulation of the anti-apoptotic proteins BCL2 and MCL1 in NK cells [11-13]. Conditional deletion of $B c l 2$ or $M c l l$ in NK cells results in a $90 \%$ and
$100 \%$ loss of NK cells in vivo, respectively $[11,12]$. Furthermore, inhibition of BCL2 function by the BCL2 inhibitor Venetoclax results in profound loss of NK cell numbers in vivo [14]. These findings indicate that manipulation of BCL2 or MCL1 may allow control of recipient NK cells prior to alloSCT, lowering the donor engraftment threshold and permitting the use of RIC to achieve durable donor $\mathrm{T}$ cell engraftment. Furthermore, by limiting proinflammatory tissue damage associated with MAC this approach may limit the onset of GVHD while maintaining the strong GVL effect mediated by donor T cells.

Here we describe a novel conditioning regime combining RIC with manipulation of recipient NK cell function. We found that genetic or pharmacological ablation of recipient NK cells by targeting BCL2 impaired rejection of donor $\mathrm{T}$ cells in recipients receiving RIC, thus permitting durable $\mathrm{BM}$ engraftment, protective graft-versus-AML, and no GVHD.

\section{Materials and methods}

\section{Experimental mice}

Experimental mice were specific-pathogen-free (SPF) and all animal work was conducted with standard operating procedures approved by institutional animal ethics committees.

WT Balb/C and C57BL/6 mice were bred and maintained at the Clive and Vera Ramaciotti Laboratories at Kew, the primary breeding facility of the Bioservices Department of the Walter and Eliza Hall Institute of Medical Research (WEHI). Bcl2-loxP [15], Mcll-loxP-hCD4 [12], and Ncrl-iCre [16] mice were backcrossed for more than 10 times to a C57BL/6 background and were bred and housed at Parkville, WEHI. The $\mathrm{Mcll}^{f l f l} \mathrm{Ncrl}^{i \mathrm{Cre}}$ mice that have complete NK cell-deficiency, the $B c l 2^{f / f l} N c r 1^{i C r e}$ mice that have $90 \%$ reduction of mature NK cells, and the $\mathrm{Mcll}^{\mathrm{fl}+\mathrm{N}} \mathrm{Ncrl}^{\mathrm{iCre}}$ that have $50 \%$ reduction of mature NK cells were used as recipients. All the mice as recipients for transplantation were 6-14 weeks of age when the experiments were set up. And the donors were 6-8 weeks of age. Mice for other experiments were between 6 and 14 weeks of age and were all females if not specified.

\section{Allogeneic SCT model}

Mice with $\mathrm{C} 57 \mathrm{BL} / 6$ background $\left(\mathrm{H}-2 \mathrm{~K}^{\mathrm{b}}\right)$ were used as alloSCT recipients, and allogeneic donors were $\mathrm{Balb} / \mathrm{C}$ $\left(\mathrm{H}-2 \mathrm{~K}^{\mathrm{d}}\right)$. The recipients received split-dose TBI by a cobalt60 (Co60) irradiator, of either a lethal $(2 \times 600 \mathrm{rad})$ or sublethal dose $(2 \times 400 \mathrm{rad})$. BM and splenocytes were collected from $\mathrm{BALB} / \mathrm{c}$ donors, and $\mathrm{CD} 4^{+}$and $\mathrm{CD} 8^{+}$ 
$\mathrm{T}$ cells were purified from splenocytes by the MACS separation method using CD4 (L3T4) and CD8a (Ly-2) MicroBeads (Miltenyi Biotech), which were mixed at a 2:1 ratio. $7.5 \times 10^{6} \mathrm{BM}$ cells $+1 \times 10^{6} \mathrm{~T}$ cells in $200 \mathrm{ml}$ phosphate-buffered saline (PBS) were injected i.v. into recipients at least $2 \mathrm{~h}$ after irradiation.

\section{Generation of AML-AF9 cells}

C57BL/6 BM stem cells were transduced with the fusion gene MLL-AF9. The MLL-AF9-GFP/Luciferase-mCherry leukemia cell line was obtained by transducing MLL-AF9 AML cells with Luciferase-mCherry retrovirus. Retrovirus was generated by transfecting HEK-293T cells with gagpol, env, and MLL-AF9-GFP with the Effectene Transfection Kit (Qiagen ${ }^{\circ}$ ). Plasmids were transfected into HEK293T cells with the Effectene ${ }^{\star}$ Transfection Kit (Qiagen ${ }^{\circ}$ ). Virus supernatant was harvested as instructed by the Effectene ${ }^{\circ}$ transfection protocol. C57BL/6 Lineage ${ }^{+}$cells were labeled with magnetic beads and depleted by EasySep $^{\mathrm{TM}}$ magnet (STEMCELL ${ }^{\mathrm{TM}}$ Technologies). Lineage ${ }^{-}$ cells were then added into the virus supernatant in six-well plates and centrifuged at $2200 \mathrm{rpm}$ for $1 \mathrm{~h}$ at $30^{\circ} \mathrm{C}$ with $4 \mu \mathrm{g} / \mathrm{ml}$ polybrene, and incubated $\left(37^{\circ} \mathrm{C}, 5 \% \mathrm{CO}_{2}\right)$ overnight. MLL-AF9-GFP/Luciferase-mCherry cells were injected i.v. into WT C57BL/6 recipients. When the recipients developed splenomegaly, leukemia cells were obtained by sorting $\mathrm{GFP}^{+}$cells from either splenocytes or $\mathrm{BM}$ cells, and used for the GVL model described below.

\section{GVL models}

Our first GVL model was used in C57BL/6 WT or Bcl2 $2^{f / f l}$ mice, to compare the effect of donor cell engraftment and GVL response in combination with RIC and alloSCT. AlloSCT recipients were given TBI $(2 \times 600$ or $2 \times 400 \mathrm{rad})$ and injected with $7.5 \times 10^{6} \mathrm{Balb} / \mathrm{C} \mathrm{BM}+1 \times 10^{6} \mathrm{~T}$ cells i.v. On day $1,8 \times 10^{5}$ AML-AF9 cells were injected i.v. Our second GVL model established AML prior to NK cell depletion and alloSCT. On day 0 WT C57BL/6 mice were inoculated with $8 \times 10^{5}$ AML-AF9 cells i.v., on days 8 and 9 mice were treated with ABT-199 or vehicle by oral gavage, and on day 10 mice were administered $2 \times 400 \mathrm{rad}$ TBI and alloSCT as described above. Mice were monitored daily for GVHD, irradiation sickness, and leukemia syndrome post-transplantation for up to 30 days.

\section{Flow cytometry analysis}

Multiple organs or tissue samples were analyzed by flow cytometry. Single-cell suspensions were obtained from organs or tissue samples and were prepared in fluorescent activated-cell sorting (FACS) buffer (PBS $+2 \%$ (V/V)
FCS). For staining panels containing surface markers only, cells were stained with various fluorescent or biotinconjugated antibodies for $30 \mathrm{~min}$ at $4{ }^{\circ} \mathrm{C}$. Cells were washed twice with FACS buffer and were then stained with fluorescent conjugated streptavidin if biotinylated antibody had been used. Cells were then resuspended in FACS buffer with a cell-viability dye: $1 \mu \mathrm{g} / \mathrm{ml}$ propidium iodide (Invitrogen $^{\mathrm{TM}}$ ), or $1 \mu \mathrm{M}$ SYTOX ${ }^{\circ}$ Blue (Invitrogen ${ }^{\mathrm{TM}}$ ), or $2 \mu \mathrm{M}$ Fluoro-Gold (Invitrogen ${ }^{\mathrm{TM}}$ ). BD LSRFortessa ${ }^{\mathrm{TM}} \mathrm{X}-20, \mathrm{BD}$ FACSVerse $^{\mathrm{TM}}$, BD FACS Canto ${ }^{\mathrm{TM}}$, and BD LSR II cytometers were used to acquire samples depending on the compatibility of the staining panel and the configuration of the cytometer.

\section{ABT-199 treatment}

The molecular formula of ABT-199 is $\mathrm{C}_{45} \mathrm{H}_{50} \mathrm{ClN}_{7} \mathrm{O}_{7} \mathrm{~S}$, and the molecular weight is $868.4 \mathrm{~g} / \mathrm{mol}$. ABT-199 inhibits BCL-2 as a BH-3 mimetic. Mice were treated with ABT199 (Active Biochem) or vehicle control by oral gavage $(100 \mathrm{mg} / \mathrm{kg})$ on two consecutive days immediately prior to TBI and alloSCT. ABT-199 was formulated in $60 \%$ phosal ${ }^{\circ}$ 50 PG (standardized phosphatidylcholine concentrate with at least 50\% PC and propylene glycol; Phospholipid GmbH, Cologne, Germany), 30\% polyethylene glycol (PEG) 400, and $10 \%$ ethanol.

\section{Statistical analysis}

Statistical analyses were performed using Prism 7 (GraphPad Software). Kurskal-Wallis test, Mann-Whitney tests, Log-Rank Mantel-Cox test, Student $t$-test and two-way ANOVA tests with Bonferroni correction were used as indicated in the figure legends. Significance is indicated as follows:

${ }^{*} p<0.05 ; * * p<0.01 ; * * * p<0.001$ and $* * * * p<0.0001$.

\section{Results}

\section{Irradiation dose differentially impacts on recipient cytotoxic lymphocyte frequency and alloSCT engraftment}

Recipient NK cells act as a barrier to alloSCT engraftment. To investigate the effects of RIC versus myeloablative total body irradiation (TBI) on recipient cytotoxic lymphocytes, C57BL/6 mice were irradiated with $800 \mathrm{rad}(2 \times 400)$ or $1200 \mathrm{rad}(2 \times 600)$. Myeloablative dose of $1200 \mathrm{rad}$ resulted in a significant reduction of splenic myeloid, $\mathrm{CD} 8^{+} \mathrm{T}$ cells, and NK cells after $96 \mathrm{~h}$, compared to $800 \mathrm{rad}$ (RIC; Fig. 1a). In the bone marrow, all immune cell populations were significantly reduced at $1200 \mathrm{rad}$ compared to $800 \mathrm{rad}$, 

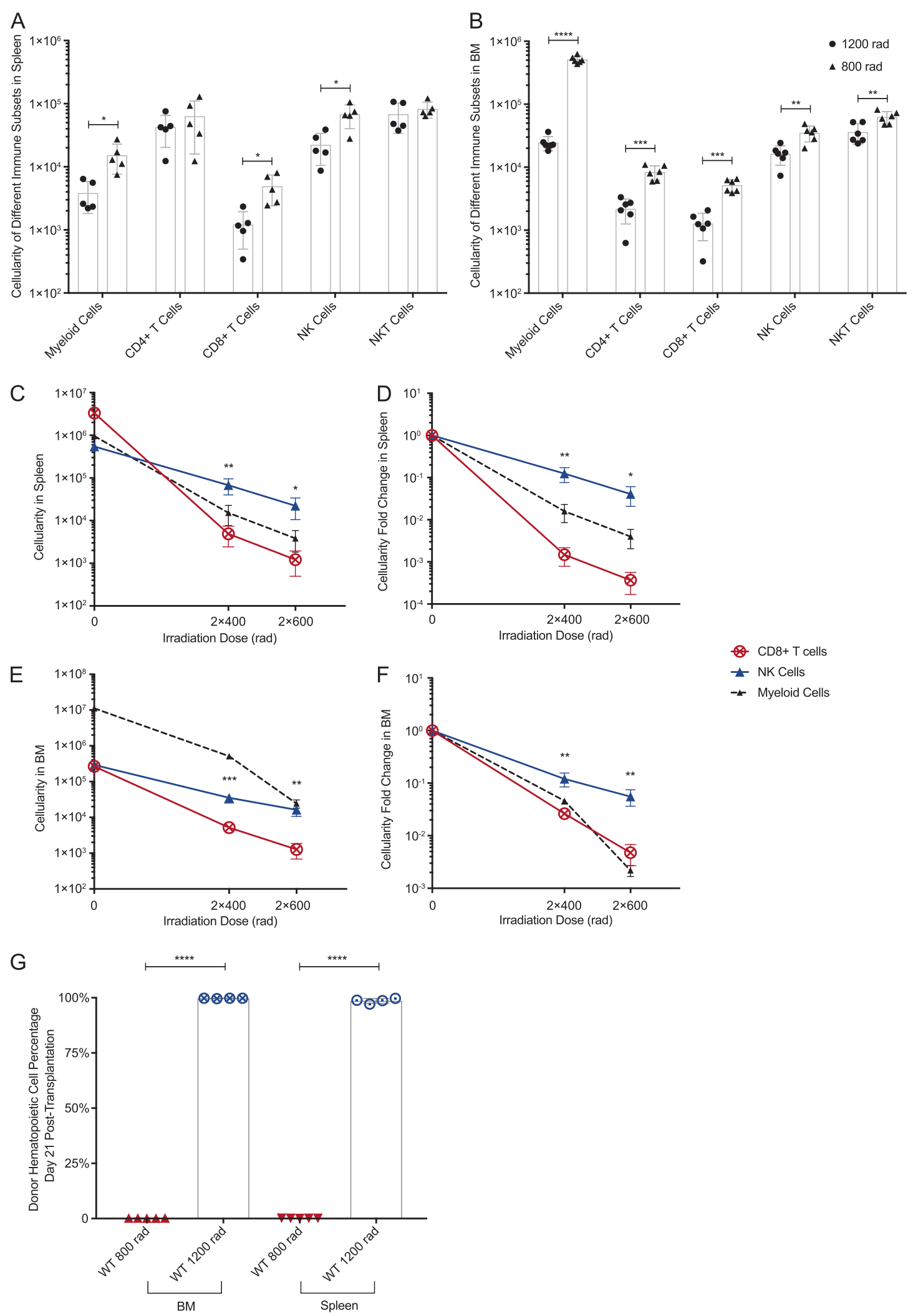

although NK were less affected (Fig. 1b). NK cells were reduced 3000-fold compared to non-irradiated mice, while significantly more radio-resistant than $\mathrm{CD} 8^{+} \mathrm{T}$ cells at both myeloablative and RIC TBI doses. At $1200 \mathrm{rad}$, splenic NK cells were only reduced 20-fold (Fig. 1c, d). At 800 rad, $\mathrm{CD}^{+} \mathrm{T}$ and myeloid cells remained significantly more $\mathrm{CD}^{+} \mathrm{T}$ cells were highly sensitive to irradiation, and were sensitive to irradiation than NK cells, undergoing a 1000- 
Fig. 1 Dosage-dependent effect of total body irradiation (TBI) on host immune system and transplantation outcome. C57BL/6 mice were irradiated with $2 \times 600$ or $2 \times 400 \mathrm{rad}$. After $96 \mathrm{~h}$ a splenocytes and b bone marrow $(\mathrm{BM})$ cells were analyzed by flow cytometry. Each point represents a single mouse ( $n=5$, unpaired $t$-test with Welch's correction). $\mathbf{c}$ Total $\mathrm{CD} 8^{+} \mathrm{T}$ cells, $\mathrm{NK}$, and myeloid cell numbers were enumerated from spleens of untreated, 800 and 1200 rad treated mice, and $\mathbf{d}$ fold-reduction for 800 and 1200 rad compared to untreated mice. e Total $\mathrm{CD}^{+}, \mathrm{NK}$, and myeloid cell numbers were calculated in BM of untreated, 800 and 1200 rad treated mice, and $\mathbf{f}$ fold-reduction for 800 and $1200 \mathrm{rad}$ compared to untreated mice. g C57BL/6 mice were irradiated with $2 \times 600$ or $2 \times 400 \mathrm{rad}$, and were then injected i.v. with $7.5 \times 10^{6}$ BM cells and $1 \times 10^{6} \mathrm{~T}$ cells from donor Balb/C $\left(\mathrm{H}-2 \mathrm{~K}^{\mathrm{d}+}\right)$ mice. Twenty-one days later, $\mathrm{CD} 45^{+}$cells in the blood were analyzed for donor hematopoietic cell $\left(\mathrm{H}-2 \mathrm{~K}^{\mathrm{d}+}\right)$ engraftment. Representative data are shown for one experiment ( $n=5$ /group), from more than five independent experiments. Error bars denote mean \pm SD. $p<0.05\left(^{*}\right)$, $p<0.01(* *), p<0.001(* * *), p<0.0001(* * * *)$

fold reduction in cellularity in the spleen, whereas only a 10-fold reduction in NK cells was observed (Fig. 1c-f). The persistence of radio-resistant NK cells has implications for rejecting donor cells at both myeloablative and RIC irradiation doses. However, the myeloablative TBI dose of $1200 \mathrm{rad}$ permitted long-term allogeneic donor cell engraftment, $800 \mathrm{rad}$ did not (Fig. 1g). Therefore, radioresistant recipient NK cells are likely to mediate alloSCT rejection at RIC TBI doses.

\section{Reducing recipient NK cells permits long-term alloSCT at reduced irradiation intensity without causing GVHD}

NK cells act as a barrier to alloSCT engraftment. We hypothesized that reduced NK cell frequency could permit alloSCT without MAC. We generated two C57BL/6 strains that conditionally lack either of the dominant BCL2-family members in NK cells, Mcl1, or Bcl2. Bcl2 $2^{f / f l} N c r l^{i C r e}$ mice possess $10 \%$ of normal NK cells whereas $\mathrm{Mcll}^{f / f l} \mathrm{Ncrl} I^{i \mathrm{Cre}}$ mice lack all NK cells $[11,12]$. Loss of one copy of Mcll $\left(\mathrm{Mcll}^{\mathrm{fl} /+} \mathrm{Ncrl} \mathrm{I}^{\mathrm{iCre}}\right)$ results in a $50 \%$ reduction in $\mathrm{NK}$ cells [12]. These graded models of NK cell lymphopenia were used to assess the contribution of radio-resistant NK cells to alloSCT outcomes.

Mice with reduced recipient NK cells and controls were conditioned with $800 \mathrm{rad}$ of TBI prior to alloSCT and monitored for signs of GVHD and donor engraftment $\left(\mathrm{H}-2 \mathrm{~K}^{\mathrm{d}}\right)$. WT mice conditioned with $1200 \mathrm{rad}$ prior to alloSCT served as positive controls (Fig. 2a, b). As expected, only the WT 1200 rad group displayed signs of GVHD (clinical score of 3 at day 13) while no groups lost greater than $10 \%$ body weight. However, WT and $\mathrm{Mcll}^{\mathrm{fl} / \mathrm{N}} \mathrm{Ncrl} \mathrm{C}^{\mathrm{iCre}} 800 \mathrm{rad}$ recipients showed signs of graft failure after day 15 (Fig. 2b).

Mice lacking NK cells $\left(B c l 2^{f / f l} N c r l^{i C r e}\right.$ and Mcll $I^{f l f l} \mathrm{Ncrl}^{i C r e}$ ) showed high rates of donor engraftment following RIC. While the levels of donor engraftment in $\mathrm{Mcll}^{\mathrm{fl} / \mathrm{fl}} \mathrm{Ncrl} \mathrm{l}^{\mathrm{iCre}}$ recipients were variable, all $B c l 2^{f l / f l} N c r l^{i C r e}$ recipients showed uniformly high (>90\%) durable engraftment (Fig. 2c and data not shown). In contrast, $\mathrm{Mcll}^{\mathrm{fl}+\mathrm{N}} \mathrm{Nrl} \mathrm{I}^{\mathrm{iCre}}$ and WT recipients conditioned with $800 \mathrm{rad}$ failed to engraft $(<1 \%$; Fig. 2c). Given the uniformly high and durable donor engraftment in $B c l 2^{f l / f} \mathrm{Ncrl} l^{i C r e}$ recipients, we next compared donor engraftment in $B c l 2^{f l f l} N c r l^{i C r e}$ RIC recipients to WT recipients following myeloablative TBI. We observed identical levels of donor engraftment (Supplemental Fig. 1) under each condition indicating that RIC of recipients with low NK cell frequencies permits full donor engraftment (Fig. 2d). Analysis of serum cytokines revealed similar cytokine production between $800 \mathrm{rad}$ $B c l 2^{f / f l} \mathrm{Ncrl}^{i \mathrm{Cre}}$ recipients and $1200 \mathrm{rad}$ WT recipients (Supplemental Fig. 2). In contrast, graft failure in $800 \mathrm{rad}$ WT mice was characterized by a significant spike in GMCSF levels 7 days post reconstitution (Supplemental Fig. 2). We next compared the degree of GVHD by gut histology based on the following criteria: mucosa integrity/ulceration; lymphoid infiltration; and apoptotic cells (score of 0-3 for each, total possible score of 9) [17]. Higher pathological scores are proportional to the severity of aGVHD lesions. Only WT recipients conditioned with myeloablative TBI showed signs of significant gut GVHD at day 40 (Fig. 2e, f). Collectively this suggests that the use of RIC and NK cell ablation permits donor engraftment and avoids GVHD.

\section{Therapeutic inhibition of BCL2 impairs murine and human NK cell survival}

The BCL2 inhibitor Venetoclax is FDA-approved for treatment of $\mathrm{B}$ cell malignancies. NK cells express MCL1 and BCL2 and both proteins are essential for NK cell survival in mice. We recently demonstrated the pro-apoptotic effect of the BCL2 inhibitor, ABT-199, on murine NK cells in vitro $[11,14]$. To determine if the effect of ABT-199 on NK cells could be exploited clinically, we assayed human NK cell survival in a range of IL-15 and ABT-199 concentrations. Supra-physiological concentrations of IL-15 protected human NK cells from apoptosis mediated by ABT-199. However, as IL-15 concentrations were reduced, a dose-dependent effect of ABT-199 was observed (Fig. 3a). When viable NK cells from these cultures were interrogated for intracellular MCL1 we noted that ABT-199 treatment selectively killed NK cells expressing low levels of MCL1 (Fig. 3b) consistent with murine data [11, 13, 18]. We next tested the efficiency of ABT-199 to induce lymphocyte apoptosis in vivo. Two-consecutive daily oral doses of $100 \mathrm{mg} / \mathrm{kg}$ ABT-199 was safe and all lymphoid populations were significantly reduced in mice $96 \mathrm{~h}$ after 

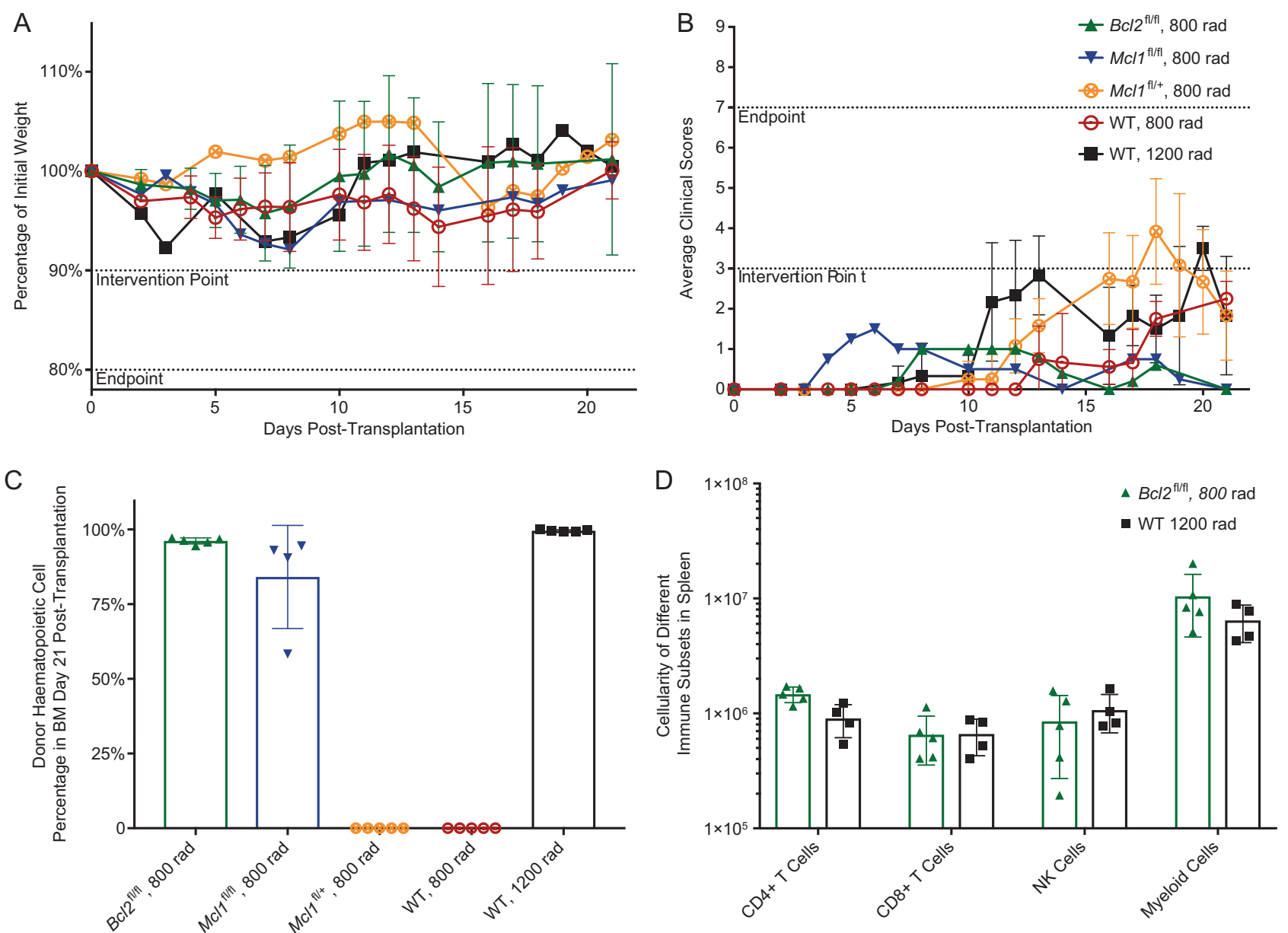

E

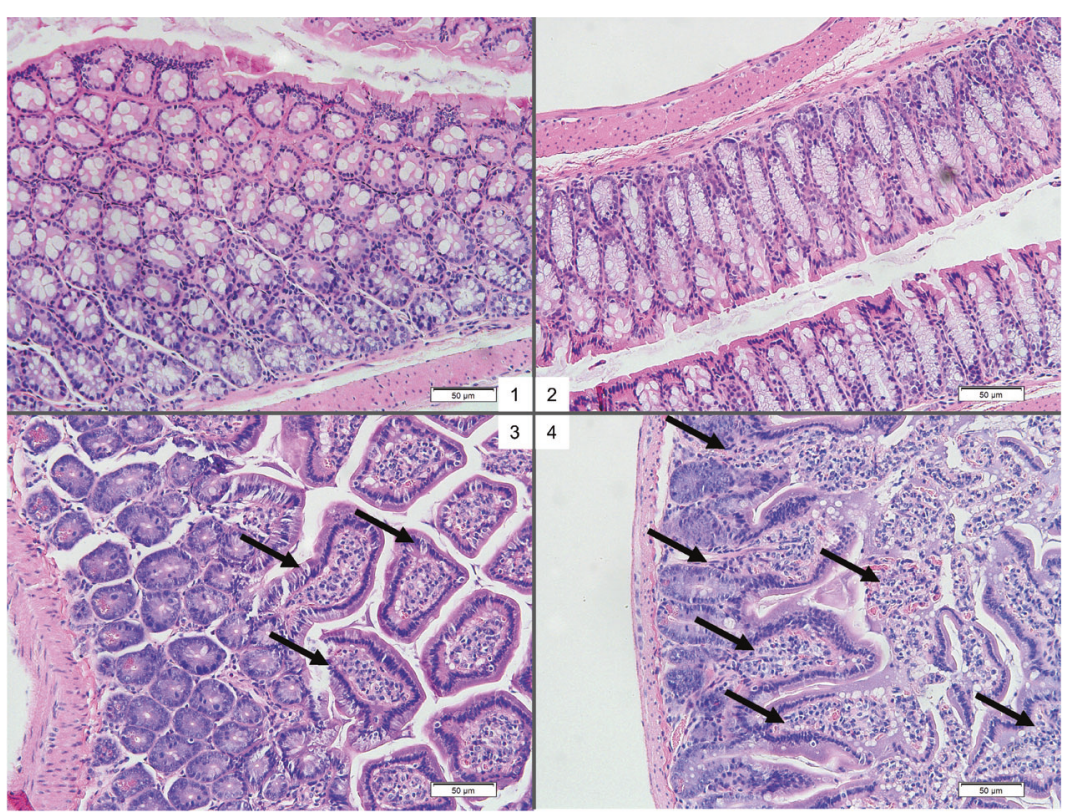

$\mathrm{F}$

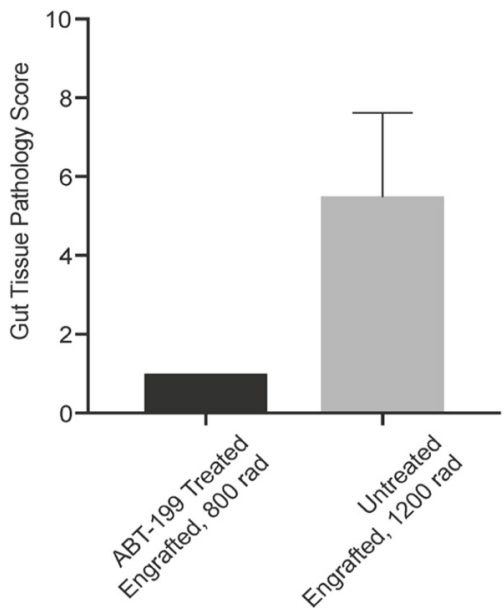

receiving ABT-199. Myeloablation following ABT-199 was observed in the spleen but not in the BM (Fig. 3c, d). Consistently, murine NK cells also expressed higher levels of MCL1 $24 \mathrm{~h}$ post ABT-199 treatment compared to vehicle (Fig. 3e). Collectively, these results indicate that BCL2 inhibition efficiently induces NK cell 
Fig. 2 Genetic depletion of recipient NK cells permits complete donor engraftment with RIC TBI, in the absence of acute GVHD. C57BL/6 mice, $\mathrm{Bcl}^{f l / f l}, \mathrm{Mcll}^{f / / f l}, \mathrm{Mcll}^{f / /}$ mice (all $\mathrm{Ncrl}-\mathrm{iCr} \mathrm{C}^{+}$) were irradiated with RIC $2 \times 400 \mathrm{rad}$, and another group of C57BL/6 mice were irradiated with $2 \times 600 \mathrm{rad}$ as the myeloablative (positive) control. All recipient mice were transplanted with $7.5 \times 10^{6} \mathrm{BM}$ cells and $1 \times$ $10^{6} \mathrm{~T}$ cells from Balb/C donors. a Body weight and $\mathbf{b}$ clinical scores were recorded over 21 days post-alloSCT. c Twenty-one days after transplantation, donor engraftment was analyzed by flow cytometry. d Enumeration of immune cells in spleens. Each data point represents an individual mouse. Error bars denote mean \pm SD. e At 40 days postalloSCT, gut tissue was prepared for histology and stained with hematoxylin and eosin (H\&E). Representative micrographs from the indicated groups highlight GVHD gut lesions marked with arrows. f Mean pathology scores \pm SD are shown for all mice in the indicated groups

apoptosis and high MCL1 expression is characteristic of treatment resistance.

\section{Therapeutic inhibition of BCL2 + RIC permits donor $T$ cell engraftment without GVHD}

Having established a safe and efficacious dose of ABT-199, we hypothesized that this could form part of a conditioning regime combined with RIC TBI. C57BL/6 mice were treated with ABT-199 or vehicle followed by $800 \mathrm{rad}$ and alloSCT. Weight loss and clinical scores were monitored over 16 weeks (Fig. 4a, b) while donor engraftment was monitored in the blood (Fig. 4c-f). In the RIC/ABT-199 cohort, at day 14 post-alloSCT donor cell engraftment occurred in $75 \%$ of recipients, whereas $100 \%$ of vehicletreated RIC recipients rejected the graft. We identified three patterns of engraftment in the RIC/ABT-199-treated mice. Thirty-three percent comprised the Engrafted group with stable, long-term 100\% donor cell engraftment; $42 \%$ comprised the Responder group, and presented with significant donor chimerism $(>75 \%)$ at day 14 but graft failure occurred by day 113; the remaining $25 \%$ in the nonengrafted group rejected the donor graft early post-alloSCT.

We did not detect signs of GVHD in the RIC/ABT-199 engrafted group whereas 1200 rad WT mice displayed significant signs of GVHD, peaking at 10 weeks posttransplantation. Correlating with the low overall GVHD score, RIC/ABT-199 engrafted mice also showed significantly reduced gut GVHD pathology (Supplemental Fig. 3). These data illustrate that recipient NK cell depletion by pharmacological BCL2 inhibition results in durable engraftment without the risk of GVHD.

\section{Therapeutic inhibition of BCL2 and MCL1 as part of RIC improves alloSCT without GVHD}

While genetic ablation of $\mathrm{Bcl} 2$ in NK cells resulted in donor engraftment in $100 \%$ of recipients following RIC, ABT-199 treatment only yielded a $33 \%$ durable donor engraftment rate. Increased dosing of ABT-199 alone could not improve on the $33 \%$ durable donor engraftment rate (data not shown), suggesting that ABT-199 alone was not efficient to ablate recipient NK cells required for full donor engraftment. Given that resistance to ABT-199-induced NK cell apoptosis is associated with higher MCL1 levels (Fig. 3d) we investigated the efficacy of ABT-199 treatment in $\mathrm{Mcll}^{\mathrm{fl}+\mathrm{N}} \mathrm{Ncrl} \mathrm{i}^{i \mathrm{Cre}}$ mice. NK cells from $\mathrm{Mcll}^{\mathrm{fl} / \mathrm{N}} \mathrm{Ncrl} \mathrm{I}^{i \mathrm{Cre}}$ mice express approximately $50 \%$ the MCL1 level of WT NK cells (Fig. 5a-f and Supplemental Fig. 4). As a result, Mcll $^{f /+} N_{c r l}{ }^{i C r e}$ NK cells are more sensitive to ABT-199induced apoptosis (Fig. 5g). Importantly, donor $\mathrm{T}$ cell engraftment could not be achieved in $\mathrm{Mcll}^{\mathrm{fl} / \mathrm{N}} \mathrm{Ncrl} \mathrm{I}^{\mathrm{iCre}}$ mice with RIC (Fig. 2c). When $\mathrm{Mcll}^{f / /+} \mathrm{Ncrl}^{i C r e}$ recipients were pre-treated with ABT-199 prior to RIC and alloSCT more than $80 \%$ of achieved durable full donor engraftment at day 28, whereas all vehicle-treated $\mathrm{Mcll}^{f / /} \mathrm{Ncrl} \mathrm{I}^{i \mathrm{Cre}}$ mice rejected the graft (Fig. 5h). We observed similar reconstitution in ABT-199-treated $\mathrm{Mcll}^{\mathrm{fl} /+} \mathrm{Ncrl}^{i C r e}$ recipients receiving reduced TBI, to both WT recipients receiving $1200 \mathrm{rad}$ and $B c l 2^{f l / f l} N c r 1^{i C r e}$ TBI alloSCT recipients (Fig. 5i). However, donor $\mathrm{T}$ cell engraftment was impaired in WT recipients treated with RIC/ABT-199, indicating that simultaneously inhibition of MCL1 and BCL2 is necessary in the RIC setting in order to achieve optimal donor engraftment. Importantly, none of the groups receiving $\mathrm{RIC}+\mathrm{ABT}$ 199 showed signs of GVHD despite achieving durable, full donor engraftment (Supplemental Fig. 3).

\section{Ablation of recipient NK cells by BCL2 targeting plus TBI permits the generation of a robust graft-versus- $A M L$ response following alloSCT}

The desired outcome in patients undergoing alloSCT is the generation of a curative GVL response. To determine if our reduced conditioning regime for alloSCT was able to generate a robust anti-leukemia response in recipients, we developed a model of AML. Lineage negative C57BL/6 $\mathrm{BM}$ was transduced with the mixed lineage leukemia AF9 fusion protein (MLL-AF9) and green fluorescent protein (GFP), and injected into C57BL/6 mice to generate $\mathrm{GFP}^{+}$ primary AML. When mice presented with illness, $\mathrm{GFP}^{+}$ AML cells were purified and analyzed by flow cytometry for ligands known to activate or inhibit NK cells and these expression profiles were compared to tumors known to be immunogenic to NK cells (Fig. 6a).

WT or $B c l 2^{f l / f} N c r l^{i C r e}$ C57BL/6 mice were irradiated with $800 \mathrm{rad}$ and transplanted with $7.5 \times 10^{6} \mathrm{Balb} / \mathrm{C} \mathrm{BM}+$ $1 \times 10^{6} \mathrm{~T}$ cells. The next day, $8 \times 10^{5}$ luciferase-expressing MLL-AF9 AML cells were injected i.v., and tumor burden monitored by bioluminescence imaging 20 days later. WT C57BL/6 mice irradiated with $800 \mathrm{rad}$ and transplanted with 

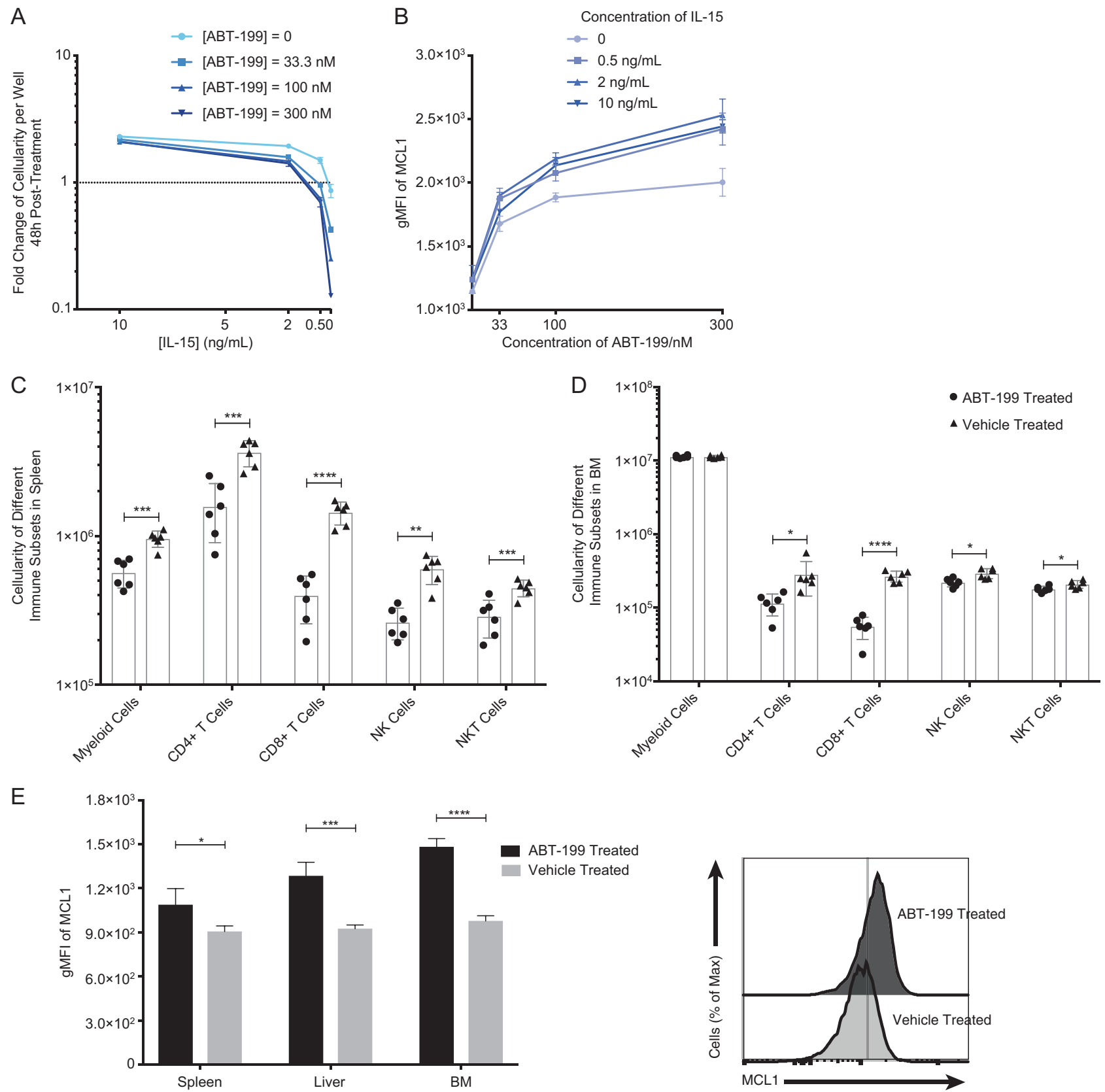

Fig. 3 The BCL-2 inhibitor ABT-199 induces NK cell apoptosis both in vitro and in vivo. Human NK cells isolated from peripheral blood mononuclear cells (PBMCs) from healthy donors were cultured with different concentrations of IL-15 and ABT-199 for $48 \mathrm{~h}$. a Foldchange in cell numbers were enumerated, and $\mathbf{b}$ mean fluorescence intensity (MFI) of intracellular MCL1 expression by flow cytometry was measured $(n=3)$. WT C57BL/6 mice were treated with ABT-199

$7.5 \times 10^{6} \mathrm{Balb} / \mathrm{C}$ Rag2 ${ }^{-1-} \gamma \mathrm{C}^{-1-} \mathrm{BM}$ cells, and WT C57BL/ 6 mice irradiated with $1200 \mathrm{rad}$ and transplanted with $7.5 \times$ $10^{6} \mathrm{Balb} / \mathrm{C}$ BM cells and $1 \times 10^{6} \mathrm{~T}$ cells, served as negative and positive controls for GVL respectively. At day 21, we could detect significant AML burden (luciferase signal) in the spleen and BM of WT mice receiving alloSCT after 800
$(100 \mathrm{mg} / \mathrm{kg})$ by oral gavage on days -2 and -1 . The mice were culled $96 \mathrm{~h}$ after the last treatment and c spleens and d BM immune cell subsets were analyzed in addition to e MCL1 expression were analyzed by flow cytometry in NK cells from different organs. Each data point represents an individual mouse. A representative FACS histogram of MCL1 is also shown. Error bars denote mean \pm SD. $p<0.05$ $(*), p<0.01(* *), p<0.001(* * *), p<0.0001(* * * *)$

rad suggesting the alloSCT had failed and no GVL response

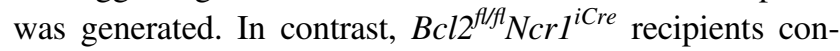
ditioned with $800 \mathrm{rad}$ displayed no evident AML in the spleen nor bone marrow and this was identical to WT mice treated with $1200 \mathrm{rad}$ prior to alloSCT (positive control; Fig. 6b). The leukemia burden detected by bioluminescence 

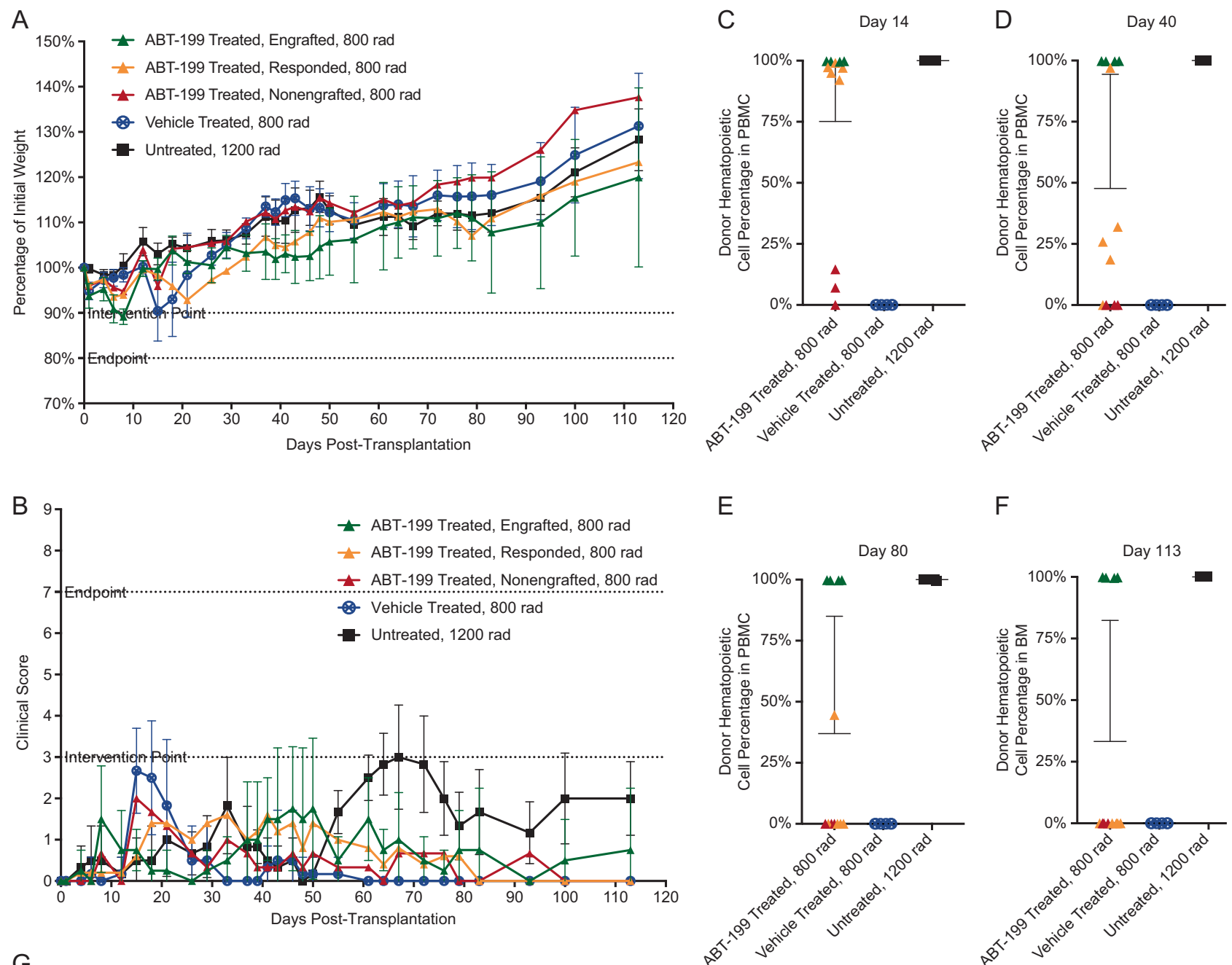

$\mathrm{F}$

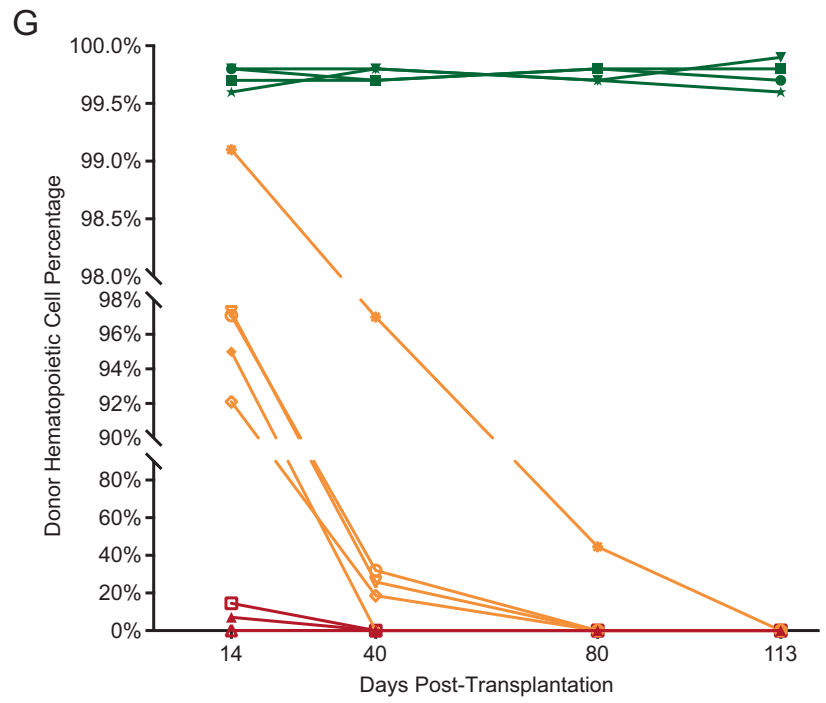

Fig. 4 ABT-199 treatment prior to RIC alloSCT improves long-term donor engraftment, with minimal GVHD. C57BL/6 mice were treated with ABT-199 $(100 \mathrm{mg} / \mathrm{kg})$ by oral gavage on two consecutive days $(n=12)$, or with equal volume of vehicle $(n=12)$, or were untreated $(n=6)$. Twenty-four hours after the last treatment, the ABT-199 and vehicle treated mice were irradiated with $2 \times 400 \mathrm{rad}$, and the untreated mice were irradiated with $2 \times 600 \mathrm{rad}$. All the mice were then transplanted with $7.5 \times 10^{6} \mathrm{BM}$ cells and $1 \times 10^{6} \mathrm{~T}$ cells from Balb/C

donors. a Mice were weighed and $\mathbf{b}$ monitored for clinical scores daily during the experiment. c-f Mice were bled at days 14, 40, 80, and 113 post-alloSCT to measure donor cell engraftment by flow cytometry. The "Engrafted" group (green) "Responder" group (yellow), and "Non-engrafted" group (red) were stratified according to their longterm engraftment response. $\mathrm{g}$ Longitudinal analysis of engraftment is shown. Each data point represents an individual mouse. Error bars denote mean \pm SD 

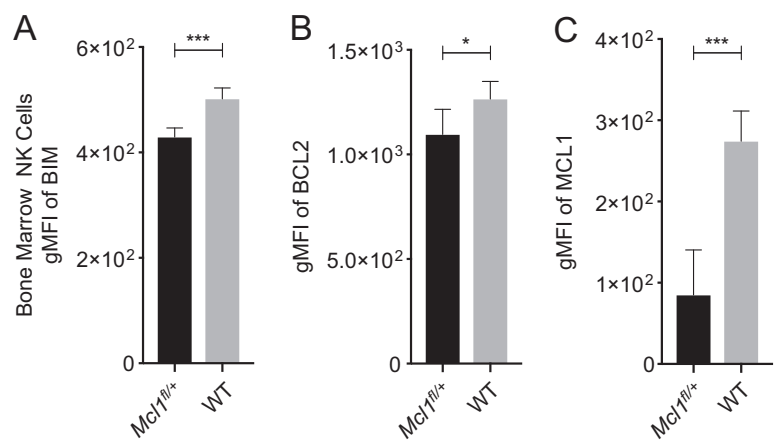

G
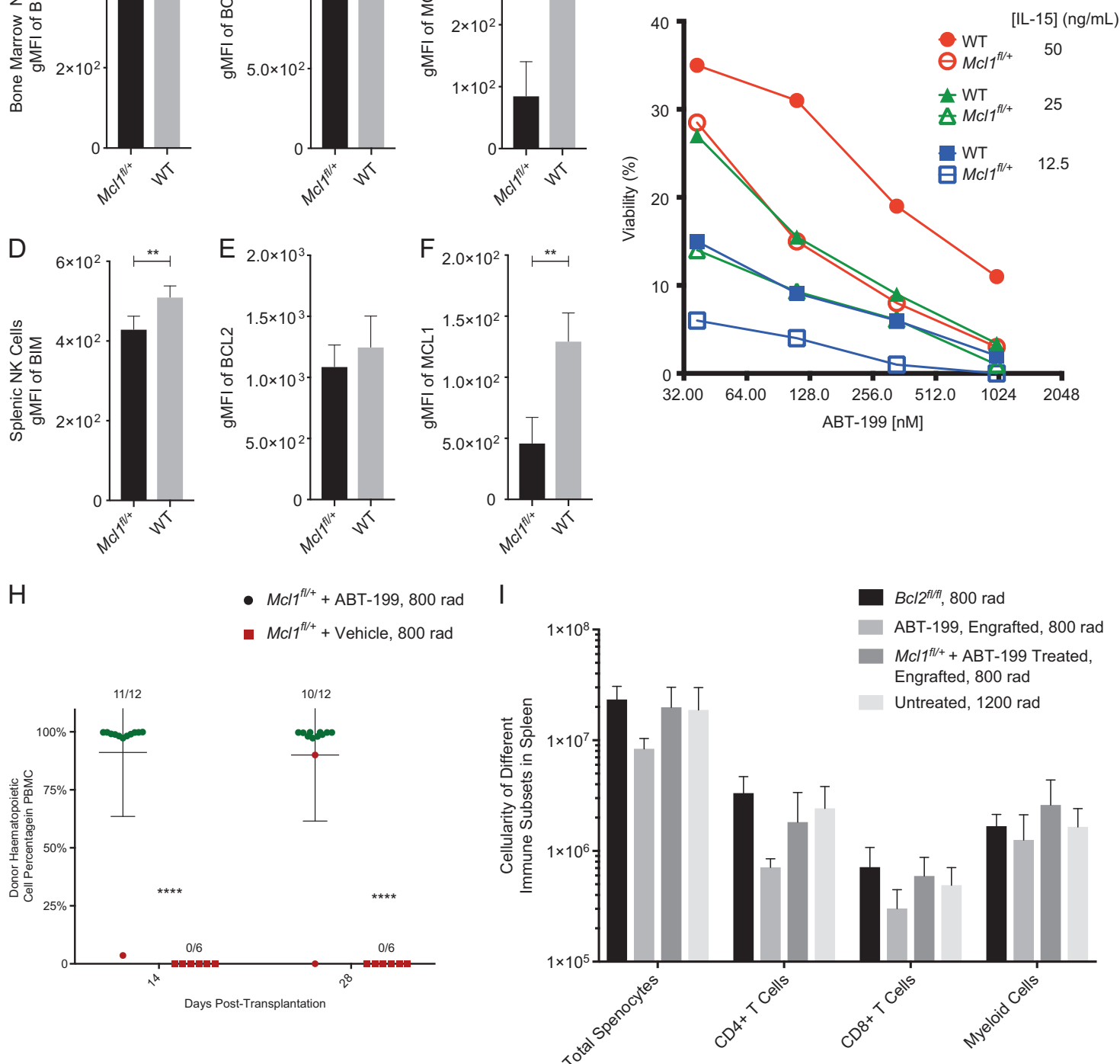

Fig. 5 Targeting both MCL1 and BCL2 improves donor cell engraftment. a-c BM cells and d-f Splenocytes were obtained from age and gender matched $\mathrm{Mcll}^{\mathrm{fl}+}$ and WT C57BL/6 mice and were analyzed for BIM, MCL1, and BCL2 expression in NK cells by flow cytometry $(n=3)$. $\mathbf{g}$ WT and $\mathrm{Mcll}^{f / /} \mathrm{NK}$ cells were enriched from splenocytes and cultured with different concentrations of IL-15 (12.5, 25 , or $50 \mathrm{ng} / \mathrm{ml})$ and ABT-199 (32-1024 $\mathrm{nM})$ for $24 \mathrm{~h}$. Viability was measured by PI exclusion and flow cytometry. $\mathbf{h ~} \mathrm{Mcll}^{f / /+}$ and C57BL/6 mice were treated twice with ABT-199 at a dose of $100 \mathrm{mg} / \mathrm{kg}$ by oral

imaging was corroborated by analysis of MLL-AF9-GFP ${ }^{+}$ leukemia cells in the blood of recipient mice at day 21 (Fig. 6c). WT alloSCT recipients treated with $800 \mathrm{rad}$ needed to be sacrificed between day 19 and 21 due to extensive leukemia burden, whereas $B c l 2^{f / f} \mathrm{Ncrl} l^{i C r e}$ mice treated identically displayed prolonged survival (Fig. 6d).

gavage $(n=12)$, or with an equal volume of vehicle $(n=6)$, followed by RIC and alloSCT. At days 14 and 28, PBMCs were obtained by retro-orbital bleeding and were analyzed for donor engraftment by flow cytometry. i At day 40, splenic immune cell subsets were analyzed by flow cytometry in different mouse models that had complete donor engraftment. Each data point represents an individual mouse. Error bars denote mean \pm SD. $p<0.05(*), p<0.01(* *), p<0.001$ $(* * *), p<0.0001(* * * *)$

$B c l 2^{f l f l} \mathrm{Ncrl}{ }^{i C r e}$ mice transplanted with WT Balb/C BM, but not $\mathrm{Rag} 2^{-1-} \gamma \mathrm{C}^{-1-}$ Balb/C bone marrow displayed full donor engraftment (Fig. 6e) corresponding to an approximate 2500-fold reduction in AML burden indicating that the anti-C57BL/6 AML immune response (GVL) was driven by donor (Balb/C) hematopoietic cells (Fig. 6f). This 
A
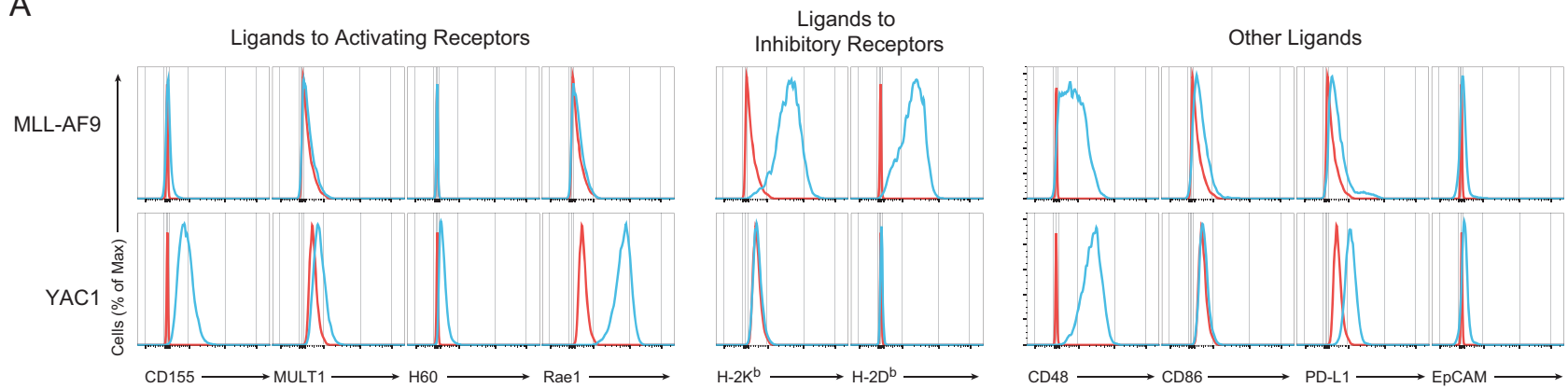

B

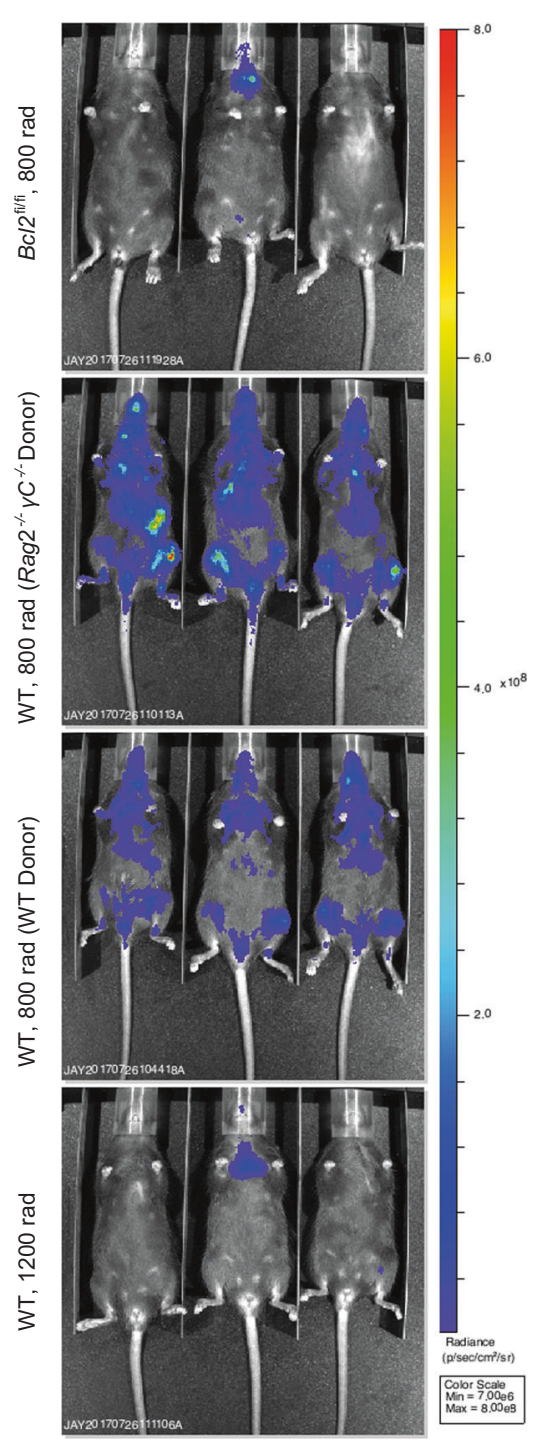

C

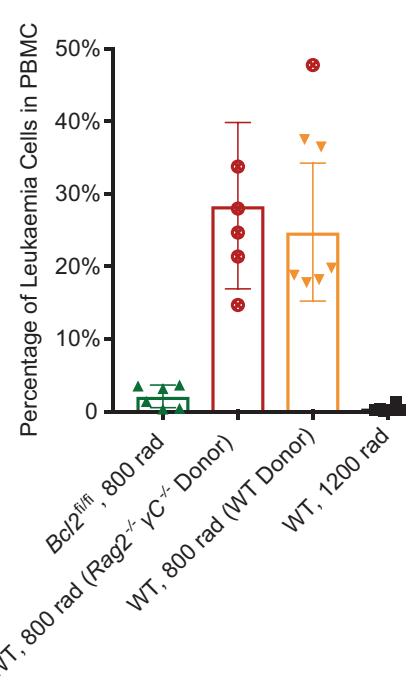

D TBI and BMT
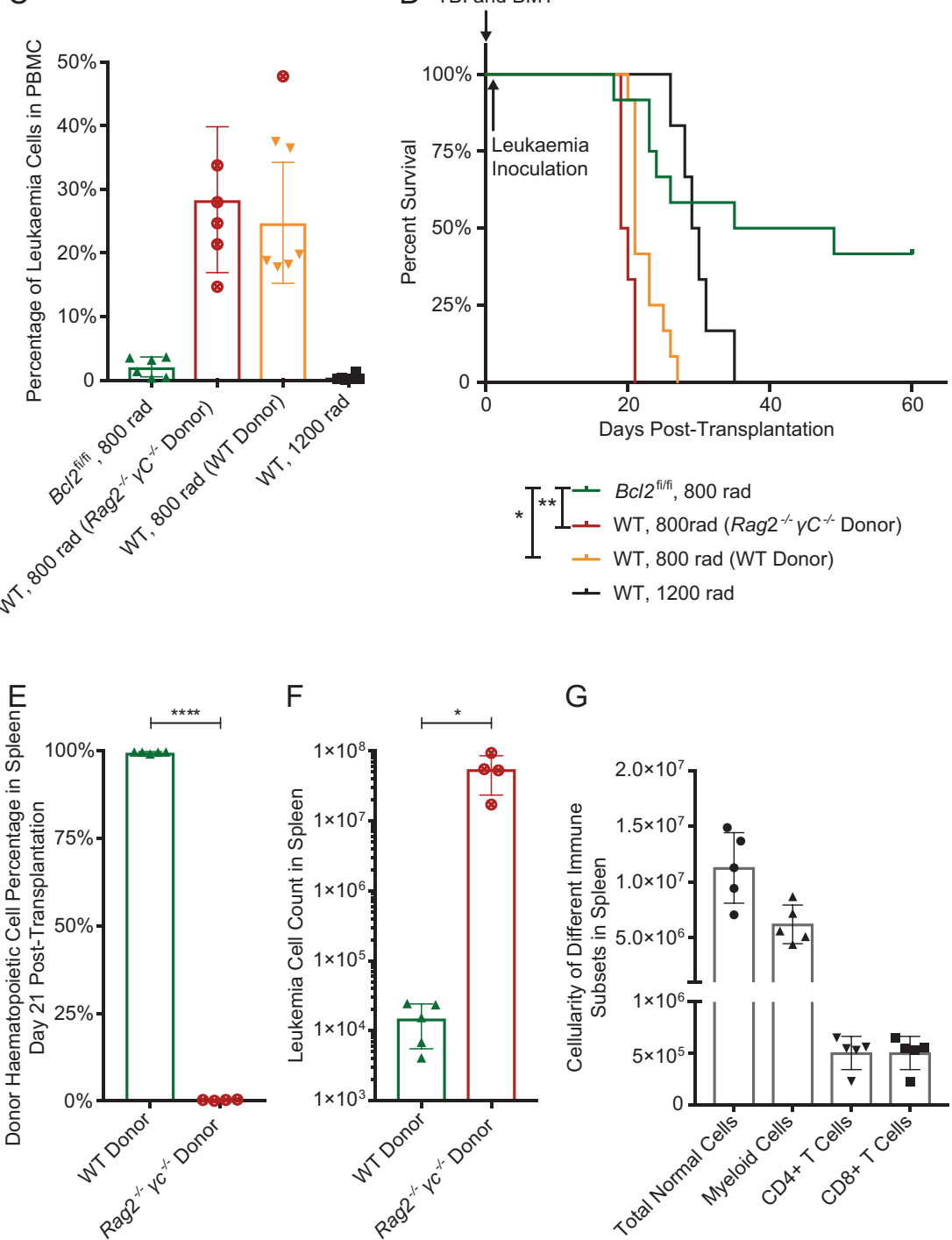

$\mathrm{F}$

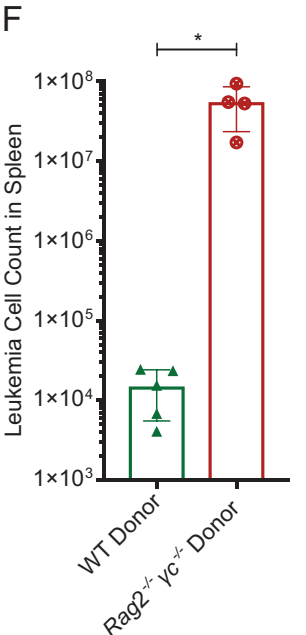

G

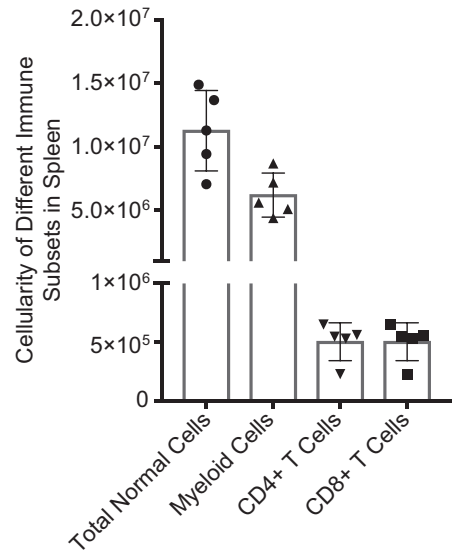

GVL response corresponded with an increased proportion of allogeneic $\mathrm{CD} 8^{+} \mathrm{T}$ cells in $\mathrm{Bcl} 2^{f l / f} \mathrm{Ncrl}^{i C r e}$ recipients, as the $\mathrm{CD}^{+}: \mathrm{CD}^{+} \mathrm{T}$ cell ratio was $1: 1$ in leukemia-bearing mice at day 21 , whereas it is typically $2: 1$ following RIC TBI and alloSCT (Fig. 6g).

\section{ABT-199 plus RIC TBI generates a robust GVL response following alloSCT}

To mimic the clinical setting of alloSCT as a treatment for AML, we next established a protocol of treating C57BL/6 
Fig. 6 The GVL effect is maintained in NK cell-deficient RIC alloSCT recipients. a Phenotypical analysis of ligands that impact on immune reactivity on MLL-AF9 leukemia and YAC-1 leukemia. $B c l 2^{f / f l}$ and WT C57BL/6 mice received RIC $800 \mathrm{rad}$ and were transplanted with $7.5 \times 10^{6} \mathrm{BM}$ cells and $1 \times 10^{6} \mathrm{~T}$ cells from WT Balb/C donors, or

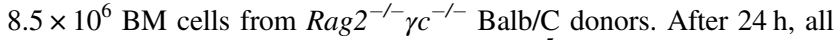
SCT recipients were injected i.v. with $8 \times 10^{5}$ MLL-AF9 AML cells. b Twenty-one days post-SCT (20 days after leukemia inoculation), bioluminescence imaging (BLI) was conducted to identify AML burden, which was measured in radiance units. c AML burden in the blood was measured by flow cytometry at day 21 and $\mathbf{d}$ survival curves were determined over 40 days post-SCT; $p=0.025(*), p=0.014$ (**) Log-Rank Mantel-Cox test. Bcl ${ }^{f l / f l}$ mice received RIC $800 \mathrm{rad}$ and were transplanted with $7.5 \times 10^{6} \mathrm{BM}$ cells and $1 \times 10^{6} \mathrm{~T}$ cells from WT Balb/C donors, or $8.5 \times 10^{6} \mathrm{BM}$ cells from Rag2 ${ }^{-/-} \gamma \mathrm{c}^{-/-} \mathrm{Balb} / \mathrm{C}$ donors. After $24 \mathrm{~h}$, all SCT recipients were injected i.v. with $8 \times 10^{5}$ MLL-AF9 AML cells. At day 21 post-SCT, some cohorts of mice were killed to examine e donor cell engraftment in splenocytes, $\mathbf{f}$ AML burden, and $\mathbf{g}$ composition of donor immune subsets. Each data point represents an individual mouse. Error bars denote mean \pm SD. $p<0.05$ $(*), p<0.0001(* * * *)$

mice bearing AML with ABT-199 + RIC TBI followed by alloSCT. Recipients were followed for 60 days following AML inoculation and 50 days post-alloSCT. Consistent with our genetic models of NK cell ablation, mice receiving ABT-199 + RIC TBI showed significantly improved survival ( $80 \%$ survival) compared to WT mice treated with vehicle + reduced TBI who had all succumb to AML by day 30 (Fig. 7a). Interestingly, mice engrafted following ABT-199 + RIC TBI had improved overall survival compared to mice engrafted after $1200 \mathrm{rad}$ alone with the latter group all succumbing to AML by day 50, whereas $50 \%$ of the ABT-199+RIC TBI group remained alive until experimental end at day 60 (Fig. 7a). Importantly, MLLAF9 AML cells are not sensitive to ABT-199 itself [19]. Supporting our previous data that resistance to AMLinduced death is mediated by a GVL response, ABT-199treated mice could again be stratified into engrafted (>99.5\% allo-engraftment) and non-engrafted (<99.5\% alloengraftment) with the engrafted group showing significantly lower AML burden in the BM and spleen than nonengrafted group 20 days following alloSCT (Fig. 7c, d). Taken together, these data demonstrate that RIC TBI in addition to NK cell ablative therapy permits a protective GVL response from engrafting $\mathrm{CD}^{+} \mathrm{T}$ cells without inducing clinical GVHD.

\section{Discussion}

New approaches to improve the safety of alloSCT are desperately needed. GVHD and relapse post-alloSCT remain the two largest barriers to successful clinical application of alloSCT. Of the current strategies to limit GVHD, only in vivo donor $\mathrm{T}$ cell depletion with anti-lymphocyte globulins (ALG) has been clinically demonstrated to significantly reduce acute and chronic GVHD incidence and severity post-alloSCT [20-25]. These studies show a variable impact on relapse rate with some demonstrating an increased relapse rate in keeping with a diminution of the GVL effect particularly after RIC [26, 27]. Evidence that the conditioning regimen impacts on GVHD and GVL has been provided by a recent randomized study [5]. In the setting of RIC, although improved tolerance of alloSCT is demonstrated by a lower treatment-related mortality and a lower rate of GVHD, relapse rates of AML following RIC are higher than following MAC. Collectively these findings demonstrate that that strategies other than variation in conditioning intensity or the deployment of ALG are needed to ensure that alloSCT can be delivered with low toxicity, robust engraftment, maintenance of the GVL effect yet still avoid GVHD.

We have established that genetic or pharmacological inhibition of recipient $\mathrm{NK}$ cell function permits robust donor engraftment and GVL without the need for MAC and, remarkably, prevents the onset of GVHD even in recipients showing durable donor $\mathrm{T}$ cell engraftment. The BCL2 antagonist Venetoclax is clinically approved in the treatment of chronic lymphocytic leukemia (CLL), and is in clinical trials for other hematological cancers [28, 29]. It is a potent inducer of apoptosis of malignant B cells expressing high BCL2 [30] and suppresses normal lymphocyte populations including $\mathrm{NK}$ cells $[11,31]$. We show that the manipulation of recipient NK cells prior to alloSCT, rather than modulation of donor $\mathrm{T}$ cell engraftment, may be used as a mechanism to modulate T cell engraftment and GVHD. Pharmacological control of recipient NK cell function permits significantly reduced conditioning and reduces organ toxicity and the pro-inflammatory cytokines that contributes to GVHD priming.

Our findings in recipients with the genetic deletion of Mcll indicate that further development of this approach of using targeted drug therapies against survival signaling pathways in recipient NK cells in combination with RIC will achieve the advantages of robust engraftment while avoiding toxicity of alloSCT is suggested by our findings in recipients with genetic deletion of $\mathrm{Mcll}$. Our data show that MCL1 loss also permits RIC while still allowing reliable engraftment and reduced GVHD. Optimization of this approach by combination of targeted therapies utilizing ABT-199 and MCL1 inhibitors [32] may allow further reductions in conditioning intensity and/or enhancement of GVL. This is relevant given that high MCL1 expression in NK cells is characteristic of ABT-199 treatment-resistance. This finding itself suggests that ABT-199 preferentially kills NK cells expressing lower levels of pro-survival proteins. Since BCL2 and MCL1 are both transcriptionally controlled by IL-15, normally distributed and essential for NK cell survival, NK cells with intrinsically higher MCL1/BCL2 
Fig. 7 The GVL effect was maintained in RIC/ABT-199conditioned alloSCT recipients. Twenty-four C57BL/6 mice were injected with $0.8 \times 10^{6}$ MLL-AF9 cells on day 0 , on days 8 and 9, 12 mice were treated with ABT-199 $(100 \mathrm{mg} / \mathrm{kg})$ by oral gavage, 6 mice were treated with equal volume of vehicle, and the remaining 6 mice were untreated. On day 10, the ABT199 and vehicle-treated mice were irradiated with $2 \times 400 \mathrm{rad}$, and the untreated mice were irradiated with $2 \times 600 \mathrm{rad}$. All the mice were injected i.v. with $7.5 \times 10^{6} \mathrm{BM}$ cells and $1 \times 10^{6}$

$\mathrm{T}$ cells from WT Balb/C donors. a Mice were monitored daily up to day 60 , and killed when AML developed. In an independent experiment at day 20 postalloSCT; $p=0.06(*)$ Log-Rank Mantel-Cox test. b Donor cell engraftment, AML burden in c BM and d spleen were measured by flow cytometry, and stratified between donor cell engrafted and non-engrafted recipients. Each data point represents an individual mouse. Error bars denote mean \pm SD. $p<0.05(*), p<0.01(* *)$, $p<0.0001(* * * *)$

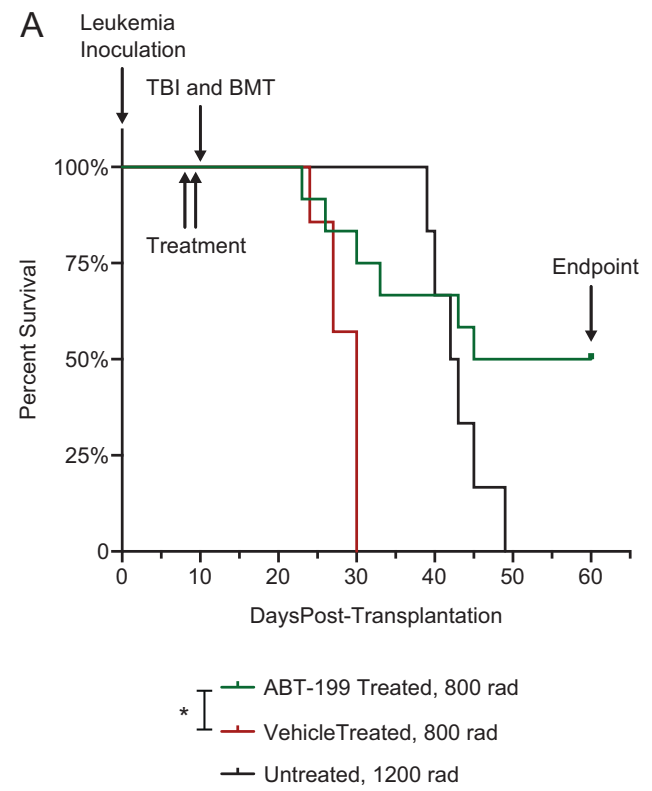

B
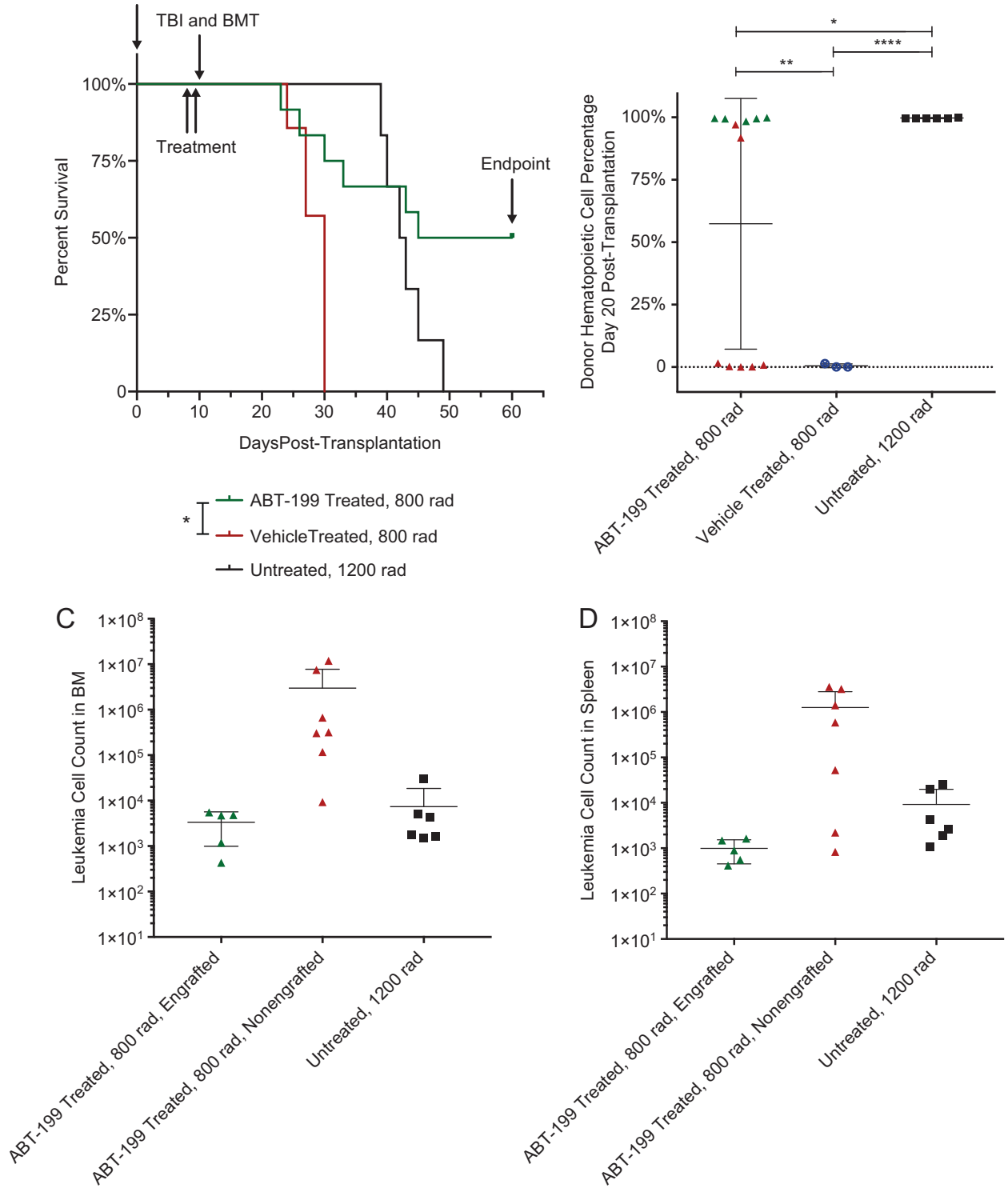

levels would be less sensitive to ABT-199. Indeed, this is what we recently concluded in mice [11]. An alternate explanation is that ABT-199-induced lymphopenia results in more bioavailable IL-15 which would induce higher MCL1 expression levels in surviving NK cells.

Other candidate drugs for recipient immune targeting include JAK inhibitors such as Ruxolitinib. JAK/STATdependent cytokines, including IL- 1 , IL- 6 , TNF- $\alpha$, and IFN- $\gamma$, have a critical role in the onset of GVHD [33, 34]. JAK inhibition also depletes NK cells by impairing IL-15R signaling [35], thus removing the IL-15-induced STAT5 binding from the $3^{\prime} \mathrm{UTR}$ of the anti-apoptotic gene $\mathrm{Mcll}$ in NK cells to promote their survival and development, while also suppressing the transcription of pro-apoptotic BIM (Bcl2l11) and NOXA (Pmaip1) [12, 13].
Ruxolitinib has been shown to reverse established GVHD through reduction of serum levels of proinflammatory cytokines and reduced expansion of alloreactive $T$ cells [36]. Similar findings have been shown in a multi-center study of patients with steroid refractory GVHD [33]. In patients undergoing alloSCT, those with Ruxolitinib resistance (and therefore more likely ongoing inflammatory cytokine production) have a poorer survival (32\% versus $91 \%$ at 2 years) [37].

Importantly, these targeted agents have an expanding role in the novel treatment of underlying hematological malignancy. Venetoclax is an established agent in the treatment of CLL and other B cell malignancies, while MCL1 inhibitors are being developed for treatment of leukemia [38]. While both types drugs are in early phase 
clinical trials as single agents for treatment of AML, recent pre-clinical findings suggest that a combination of both results in optimal control over AML growth in vivo [32] and that combination JAK2 and BCL2 inhibition may disrupt the AML stem cell niche [39].

Together with our findings, it is possible that novel combinations of BCL2/MCL1/JAK inhibitor therapy may be explored within clinical trials as a means of controlling AML prior to alloSCT and as a component of a RIC regimen prior to alloSCT that result in safer, less toxic transplants, lower GVHD onset, and optimized AML control through maintenance of the GVL effect.

Acknowledgements This work is supported by program and project grants from the National Health and Medical Research Council (NHMRC) of Australia (1049407, 1066770, 1057852, 1027472 to N. D.H.), as well as an NHMRC Independent Research Institute Infrastructure Support scheme grant and a Victorian State Government Operational Infrastructure Scheme grant. J.E.D. is supported by a Rabinowicz \& Amarant Family Cancer Research Fellowship from the Royal Melbourne Hospital Foundation. F.S.-F.G. was supported by a NHMRC Early Career Fellowship (1088703), a National Breast Cancer Foundation (NBCF) Fellowship (PF-15-008), and grant \#1120725 awarded through the Priority-driven Collaborative Cancer Research Scheme and funded by Cure Cancer Australia with the assistance of Cancer Australia. N.D.H. is a recipient of a Melanoma Research Grant from the Harry J Lloyd Charitable Trust (USA), Melanoma Research Alliance (USA), a research grant from the Ian Potter Foundation (AUS) and a CLIP grant from Cancer Research Institute (USA). This work is also supported by fellowships from the NHMRC (10461276 to N.D.H.), the Menzies Foundation (to N.D.H.), and by an enabling grant from The Fight Cancer Foundation.

Authorship contributions Y.J., J.E.D., J.R., M.J.L.-M., W.G., R.B.D., F.S.-F.G., D.S.R. and N.D.H. designed and/or performed experiments. E.M., D.G., D.H., A.M.L., B.T.K. and R.K. provided key reagents. Y. J., J.E.D., N.D.H. and D.S.R. supervised experimental design, and provided input into interpretation of results and writing of the paper.

\section{Compliance with ethical standards}

Conflict of Interest J.R. and N.D.H. are co-founders and share-holders of oNKo-innate Pty Ltd. N.D.H. has a collaborative research agreement with Servier.

\section{References}

1. Gratwohl A, Pasquini MC, Aljurf M, Atsuta Y, Baldomero H, Foeken L, et al. One million haemopoietic stem-cell transplants: a retrospective observational study. Lancet Haematol. 2015;2:e91-100.

2. Wong E, Mason K, Collins J, Hockridge B, Boyd J, Gorelik A, et al. The prognostic limitations of donor T-cell chimerism after myeloablative allogeneic stem cell transplantation for acute myeloid leukemia and myelodysplastic syndromes. Biol Blood Marrow Transplant. 2017;23:840-4.

3. Negrin RS. Graft-versus-host disease versus graft-versusleukemia. Hematol Am Soc Hematol Educ Program. 2015;2015:225-30.
4. Teshima T, Reddy P, Zeiser R. Acute graft-versus-host disease: novel biological insights. Biol Blood Marrow Transplant. 2016;22:11-16.

5. Scott BL, Pasquini MC, Logan BR, Wu J, Devine SM, Porter DL, et al. Myeloablative versus reduced-intensity hematopoietic cell transplantation for acute myeloid leukemia and myelodysplastic syndromes. J Clin Oncol. 2017;35:1154-61.

6. Lodolce JP, Boone DL, Chai S, Swain RE, Dassopoulos T, Trettin $\mathrm{S}$, et al. IL-15 receptor maintains lymphoid homeostasis by supporting lymphocyte homing and proliferation. Immunity. 1998;9:669-76.

7. Kennedy MK, Glaccum M, Brown SN, Butz EA, Viney JL, Embers M, et al. Reversible defects in natural killer and memory CD8 T cell lineages in interleukin 15-deficient mice. J Exp Med. 2000;191:771-80.

8. Ljunggren HG, Karre K. Host resistance directed selectively against H-2-deficient lymphoma variants. Analysis of the mechanism. J Exp Med. 1985;162:1745-59.

9. Davis JE, Harvey M, Gherardin NA, Koldej R, Huntington N, Neeson $\mathrm{P}$, et al. A radio-resistant perforin-expressing lymphoid population controls allogeneic $\mathrm{T}$ cell engraftment, activation, and onset of graft-versus-host disease in mice. Biol Blood Marrow Transplant. 2015;21:242-9.

10. Bunting MD, Varelias A, Souza-Fonseca-Guimaraes F, Schuster IS, Lineburg KE, Kuns RD, et al. GVHD prevents NK-celldependent leukemia and virus-specific innate immunity. Blood. 2017;129:630-42.

11. Viant C, Guia S, Hennessy RJ, Rautela J, Pham K, Bernat C, et al. Cell cycle progression dictates the requirement for BCL2 in natural killer cell survival. J Exp Med. 2017;214:491-510.

12. Sathe P, Delconte RB, Souza-Fonseca-Guimaraes F, Seillet C, Chopin M, Vandenberg CJ, et al. Innate immunodeficiency following genetic ablation of $\mathrm{Mcl} 1$ in natural killer cells. Nat Commun. 2014;5:4539.

13. Huntington ND, Puthalakath H, Gunn P, Naik E, Michalak EM, Smyth MJ, et al. Interleukin 15-mediated survival of natural killer cells is determined by interactions among Bim, Noxa and Mcl-1. Nat Immunol. 2007;8:856-63.

14. Carrington EM, Zhan Y, Brady JL, Zhang JG, Sutherland RM, Anstee NS, et al. Anti-apoptotic proteins BCL-2, MCL-1 and A1 summate collectively to maintain survival of immune cell populations both in vitro and in vivo. Cell Death Differ. 2017;24:878-88.

15. Thorp E, Li Y, Bao L, Yao PM, Kuriakose G, Rong J, et al. Brief report: increased apoptosis in advanced atherosclerotic lesions of Apoe-I- mice lacking macrophage Bcl-2. Arterioscler Thromb Vasc Biol. 2009;29:169-72.

16. Narni-Mancinelli E, Chaix J, Fenis A, Kerdiles YM, Yessaad N, Reynders A, et al. Fate mapping analysis of lymphoid cells expressing the NKp46 cell surface receptor. Proc Natl Acad Sci USA. 2011;108:18324-9.

17. Cooke KR, Hill GR, Crawford JM, Bungard D, Brinson YS, Delmonte J, et al. Tumor necrosis factor- alpha production to lipopolysaccharide stimulation by donor cells predicts the severity of experimental acute graft-versus-host disease. J Clin Invest. 1998;102:1882-91.

18. Ranson T, Vosshenrich CA, Corcuff E, Richard O, Laloux V, Lehuen A, et al. IL-15 availability conditions homeostasis of peripheral natural killer $\mathrm{T}$ cells. Proc Natl Acad Sci USA. 2003;100:2663-8.

19. Liu Q, Chen L, Atkinson JM, Claxton DF, Wang HG. Atg5dependent autophagy contributes to the development of acute myeloid leukemia in an MLL-AF9-driven mouse model. Cell Death Dis. 2016;7:e2361. 
20. Finke J, Bethge WA, Schmoor C, Ottinger HD, Stelljes M, Zander AR, et al. Standard graft-versus-host disease prophylaxis with or without anti-T-cell globulin in haematopoietic cell transplantation from matched unrelated donors: a randomised, open-label, multicentre phase 3 trial. Lancet Oncol. 2009;10:855-64.

21. Bacigalupo A, Lamparelli T, Bruzzi P, Guidi S, Alessandrino PE, di Bartolomeo P, et al. Antithymocyte globulin for graft-versushost disease prophylaxis in transplants from unrelated donors: 2 . Randomized studies from Gruppo Italiano Trapianti Midollo Osseo (GITMO). Blood. 2001;98:2942-7.

22. Wolschke C, Zabelina T, Ayuk F, Alchalby H, Berger J, Klyuchnikov E, et al. Effective prevention of GVHD using in vivo T-cell depletion with anti-lymphocyte globulin in HLA-identical or -mismatched sibling peripheral blood stem cell transplantation. Bone Marrow Transplant. 2014;49:126-30.

23. Bonifazi F, Bandini G, Arpinati M, Tolomelli G, Stanzani M, Motta MR, et al. Intensification of GVHD prophylaxis with lowdose ATG-F before allogeneic PBSC transplantation from HLAidentical siblings in adult patients with hematological malignancies: results from a retrospective analysis. Bone Marrow Transplant. 2012;47:1105-11.

24. Kroger N, Solano C, Bonifazi F. Antilymphocyte globulin for chronic graft-versus-host disease. N Eng J Med. 2016;374:1894-5.

25. Kroger N, Solano C, Wolschke C, Bandini G, Patriarca F, Pini M, et al. Antilymphocyte globulin for prevention of chronic graftversus-host disease. N Eng J Med. 2016;374:43-53.

26. Soiffer RJ, Lerademacher J, Ho V, Kan F, Artz A, Champlin RE, et al. Impact of immune modulation with anti-T-cell antibodies on the outcome of reduced-intensity allogeneic hematopoietic stem cell transplantation for hematologic malignancies. Blood. 2011;117:6963-70.

27. Remberger M, Ringden O, Hagglund H, Svahn BM, Ljungman P, Uhlin $\mathrm{M}$, et al. A high antithymocyte globulin dose increases the risk of relapse after reduced intensity conditioning HSCT with unrelated donors. Clin Transplant. 2013;27:E368-374.

28. Roberts AW, Davids MS, Pagel JM, Kahl BS, Puvvada SD, Gerecitano JF, et al. Targeting BCL2 with Venetoclax in relapsed chronic lymphocytic leukemia. N Eng J Med. 2016;374:311-22.

29. Davids MS, Roberts AW, Seymour JF, Pagel JM, Kahl BS, Wierda WG, et al. Phase I first-in-human study of Venetoclax in patients with relapsed or refractory non-Hodgkin lymphoma. J Clin Oncol. 2017;35:826-33.

30. Souers AJ, Leverson JD, Boghaert ER, Ackler SL, Catron ND, Chen J, et al. ABT-199, a potent and selective BCL-2 inhibitor, achieves antitumor activity while sparing platelets. Nat Med. 2013;19:202-8.

31. Carrington EM, Brady JL, Zhang J-G, Suttherland RM, Zhan Y, Anstee N, et al. Anti-apoptotic BCL2 family proteins as a quantitative collective maintain survival of immune cell populations. Cell Death Differ. 2017;24:878-88.

32. Teh TC, Nguyen NY, Moujalled DM, Segal D, Pomilio G, Rijal S. Enhancing venetoclax activity in acute myeloid leukemia by co-targeting MCL1. Leukemia. 2018;32:303-12.

33. Zeiser R, Burchert A, Lengerke C, Verbeek M, Maas-Bauer K, Metzelder SK, et al. Ruxolitinib in corticosteroid-refractory graftversus-host disease after allogeneic stem cell transplantation: a multicenter survey. Leukemia. 2015;29:2062-8.

34. Carniti C, Gimondi S, Vendramin A, Recordati C, Confalonieri D, Bermema A, et al. Pharmacologic inhibition of JAK1/ JAK2 signaling reduces experimental murine acute GVHD while preserving GVT effects. Clin Cancer Res. 2015;21:3740-9.

35. Bottos A, Gotthardt D, Gill JW, Gattelli A, Frei A, Tzankov A, et al. Decreased NK-cell tumour immunosurveillance consequent to JAK inhibition enhances metastasis in breast cancer models. Nat Commun. 2016;7:12258.

36. Spoerl S, Mathew NR, Bscheider M, Schmitt-Graeff A, Chen S, Mueller T, et al. Activity of therapeutic JAK $1 / 2$ blockade in graftversus-host disease. Blood. 2014;123:3832-42.

37. Shanavas M, Popat U, Michaelis LC, Fauble V, McLornan D, Klisovic R, et al. Outcomes of allogeneic hematopoietic cell transplantation in patients with myelofibrosis with prior exposure to Janus Kinase 1/2 inhibitors. Biol Blood Marrow Transplant. 2016;22:432-40.

38. Kotschy A, Szlavik Z, Murray J, Davidson J, Maragno AL, Le Toumelin-Braizat G, et al. The MCL1 inhibitor S63845 is tolerable and effective in diverse cancer models. Nature. 2016;538:477-82.

39. Karjalainen R, Pemovska T, Popa M, Liu M, Javarappa KK, Majumder MM, et al. JAK1/2 and BCL2 inhibitors synergize to counteract bone marrow stromal cell-induced protection of AML. Blood. 2017;130:789-802. 